\title{
The Number of Infants with Hepatitis B virus (HBV) added Each Day in India
} Umesh Kapil

Professor, Department of Epidemiology, Bio-statistics and Clinical Research, Institute of Liver \& Biliary Sciences, New Delhi, 10070, India

\begin{tabular}{|c|c|c|c|c|c|c|c|c|}
\hline Abstract & Introduction & Methodology & Results & Conclusion & References & Citation & \multicolumn{2}{|c|}{ Tables / Figures } \\
\hline \multicolumn{9}{|c|}{ ding Author } \\
\hline \multicolumn{8}{|c|}{$\begin{array}{l}\text { Umesh Kapil, Professor, Department of Epidemiology, Bio-statistics and Clinical Research, Institute } \\
\text { of Liver \& Biliary Sciences, New Delhi, 10070,India } \\
\text { E Mail ID: umeshkapil@gmail.com }\end{array}$} & 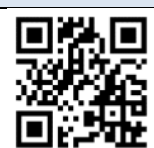 \\
\hline
\end{tabular}

\section{Citation}

Kapil U, The Number of Hepatitis B virus (HBV) Infants added Each Day in India. Indian J Comm Health. 2021;33(1):234-235. https://doi.org/10.47203/IJCH.2021.v33i01.035

Source of Funding: Nil Conflict of Interest: None declared

\section{Article Cycle}

Received: 08/03/2021; Revision: 13/03/2021; Accepted: 22/03/2021; Published: 31/03/2021

This work is licensed under a Creative Commons Attribution 4.0 International License.

Hepatitis B virus (HBV) is one of the major global public health problems.HBV infection is the 10th leading cause of death.(1) In India, HBsAg prevalence,(an indicator of chronic HBV infection) among general population ranges from $2 \%$ to $8 \%$.(2) $\mathrm{HBV}$ vaccination has been integrated in the Universal Immunization Program (UIP) for last 10 years. All new borns are expected to receive HBV vaccination at 0 day and subsequently at 6,10 and 14 weeks.

Majority of women do not know they are HBV infected. Often they do not have no symptoms. When a pregnant woman has hepatitis $B$, it can spread to her baby at birth. This can happen during a vaginal delivery or a c-section. Babies and young children can also get hepatitis B from close contact with family members or others who might be infected. When babies become infected with hepatitis B, they have about a $90 \%$ chance of developing a lifelong, chronic infection.

We would like to communicate with readers of Indian Pediatrics the scientific evidence on number of HBV infants cases which may be presently being added per day in India.

We utilized the following methodology. First We calculated the total number of births occurring in India per day. From this data, we calculated the number of children born per day whose mothers may have HBV infection. Subsequently, we calculated, the number of new borns who are 'at risk' of HBV infection from their mothers due to Mother to Child Transmission (MTCT) process per day. Finally we calculated the total number of infants who may acquire HBV infection per day

For prevention of HBV infection in Infants, it is vital that we undertake screening of all $\mathrm{HBsAg}$-positive pregnant women and give them antiviral therapy

Also, there should be provision of immunoprophylaxis for infants born to infected mothers, should be given i) hepatitis $B$ vaccine and ii) hepatitis B immune globulin within 12 hours of birth.

\section{References}

1. MacLachlan JH, Cowie BC. Hepatitis B virus epidemiology. Cold Spring Harb Perspect Med. 2015;5(5):a021410. doi: 10.1101/cshperspect.a021410. PMID: 25934461; PMCID: PMC4448582.[PubMed]

2. Makuza JD, Rwema JOT, Ntihabose CK, Dushimiyimana D, Umutesi J, Nisingizwe MP, Serumondo J, Semakula M, Riedel DJ, Nsanzimana S. Prevalence of hepatitis B surface antigen ( $\mathrm{HBsAg}$ ) positivity and its associated factors in Rwanda. BMC Infect Dis. 2019;19(1):381. doi: 10.1186/s12879-019-4013-4. PMID: 31053097; PMCID: PMC6499977.[PubMed]

3. India Population web site https://countrymeters.info/en/India [Accessed on $02 \mathrm{Feb}$ 2021]

4. Narayanswamy K. Hepatitis B and pregnancy: challenges in India. J Indian Med Assoc. 2011;109(10):766-7. PMID: 22482331. [PubMed] 
INDIAN JOURNAL OF COMMUNITY HEALTH / VOL 33 / ISSUE NO 01 / JAN- MAR 2021

5. Ministry of Health and Family Welfare. India rolls out National Viral Hepatitis Control Program https://pib.gov.in/PressReleaselframePage.aspx?PRID=156 $\underline{6140}$ [Accessed on 02 Feb 2021]

6. World Health Organization. Regional Office for the Western Pacific. (2006). Preventing mother-to-child transmission of
[Hepatitis B virus...] | Kapil $U$ et al hepatitis $B$ : operational field guidelines for delivery of the birth dose of hepatitis B vaccine. Manila : WHO Regional Office for the Western Pacific. https://apps.who.int/iris/handle/10665/272905 . License: CC BY-NC-SA 3.0 IGO

\section{Tables}

\section{TABLE 1 TOTAL NUMBER OF INFANTS WHO ARE ACQUIRING HBV INFECTION PER DAY}

\begin{tabular}{|c|c|c|}
\hline & Numbers & Comments \\
\hline Total Births per day in India (3) & 76610 & $\begin{array}{l}\text { Roughly, India is adding } 19 \text { million population every year } \\
\text { (https://www.prb.org/india-rising/). During 2019, India population is } \\
\text { projected to increased by } 17,248,911 \text { people and reach } 1,387,297,452 \\
\text { in the beginning of } 2020 .\end{array}$ \\
\hline $\begin{array}{l}\text { Out of above, the number of } \\
\text { children born per day whose } \\
\text { mothers have HBV infection } \\
\text { per day (4) }\end{array}$ & $\begin{array}{l}3064 \\
(=76610 \times 0.04)\end{array}$ & $\begin{array}{l}\text { Previous studies suggest prevalence of HBV infection in the country is } \\
4 \% \text { in the general population and among pregnant women it is } 1-9 \% \text {. } \\
\text { We assumed } 4 \% \text { of all pregnant women have HBV infection }\end{array}$ \\
\hline $\begin{array}{l}\text { Number of new born who are } \\
\text { 'at risk' of HBV infection from } \\
\text { their mothers (MTCT) per day } \\
\text { (5) }\end{array}$ & $\begin{array}{l}1226 \\
(=3064.4 \times 0.4\end{array}$ & $\begin{array}{l}\text { Since of the total live births, the hepatitis B birth dose coverage is } 60 \% \\
\text { in } 2016 \text {. We assume, } 60 \% \text { of the children who will get birth dose will } \\
\text { be protected from HBV infection. } \\
\text { With this estimate, } 40 \% \text { of the total live birth are at risk of acquiring } \\
\text { HBV infection. }\end{array}$ \\
\hline $\begin{array}{l}\text { Total number of infants who } \\
\text { will acquire HBV infection per } \\
\text { day }\end{array}$ & $\begin{array}{l}49 \\
(=1225.6 * 0.04)\end{array}$ & $\begin{array}{l}\text { Without the birth dose, an estimated } 3 \% \text { to } 5 \% \text { (Considering the } \\
\text { average as } 4 \% \text { ) of all infants born in India will acquire chronic hepatitis } \\
\text { B infection at birth.(6) }\end{array}$ \\
\hline
\end{tabular}

